\title{
Applicant's Self Confidence Influence in Employment Interview Process According to Recruiters Perceptions. An Exploratory Study in Greece
}

\author{
Andreas Dimopoulos \\ PO Box 3118, Fragma Thermis Post Code 57001, Thessaloniki, Greece \\ E-mail: job1j@yahoo.gr; info@andreasdimopoulos.gr
}

Andreas Dimopoulos (Corresponding author)

PhD Candidate Department of Economics

Faculty of Social, Political, and Economics Sciences, Democritus University of Thrace

Panepistimioupoli, Komotini 69100, Greece

E-mail: secr@econ.duth.gr

Received: xx, 2020 Accepted: xx, 2020 Online published: xx, 2020

doi:10.5296/ijhrs.v10i2.16701 URL: https://doi.org/10.5296/ijhrs.v10i2.16701

\begin{abstract}
Self confidence, self esteem and self efficacy are widely common terms in job search effectiveness according to literature. There is a consensus in a large extent that candidates' self confidence during interview process has significant influence and affects recruiters' decisions and respectively hiring results. This study aims to search the significance of employee candidates' self confidence and its relative impact in recruiters, employers, hiring decisions during employment interview. For this purpose, an empirical research has been conducted in order to explore the importance and relative impact of candidates' self-confidence in a sample of two hundred and sixty recruiters', personnel managers' and employers in Greece about the impact of candidates' self confidence, might have in their hiring decisions, during interview selection process. The significance of candidates self confidence was measured according to three specific dimensions of the recruiters decisions, which were in particular, the possibility of hiring them, the possibility of consider them as suitable for the position they applied for, and thirdly for the possibility of giving them a chance for a second interview. The three measures were analysed each one individually, and
\end{abstract}


then unified in one, with the term hireability- sellectability. The new index has been tested for cronbach's alpha measure of reliability, taking high acceptant value. Results show that employee candidates' self confidence has significant influence and affect recruiters' decisions and selection outcomes regarding this index. There is also significant impact of candidate's self confidence, in all three of interviewers' decisions options as in particular, to hire the candidates, to consider them suitable for the position and to invite them in a second interview.

Keywords: self-confidence, self efficacy, self esteem, interview, employment, selection, recruiting

JEL codes: M51, M12, J23, J21, J80, J62, 015, L20, D21, D23, F23

\section{Introduction}

1.1 Self Confidence, Self Efficacy, Self Esteem. Interpretations and Correlations with Employment Outcomes

Self-efficacy, Self-confidence, and Self esteem are very common terms with particular significance and well documented in job search literature. However, despite the fact that there are differences among them, as constructs needing conceptual clarification. Because, all of them are connected with employability and concern job search outcomes, it is considered as important in this article to be presented in thorough in order to make clear their relative differences and their particular contribution to employment outcomes.

This study focuses on Self-Confidence exclusively and analyse the term regarding its influence in recruiters decisions in employment interview. However, employment interview is the last stage of a job search process in which all these terms have a significant direct or indirect influence. Moreover, employment interview is also a behavioral process through a candidate can convey and present during it, his self confident. Nevertheless, self-esteem and self-efficacy as behavioral properties, affect the final result from the very beginning of job search process, either through the composition of an effective $\mathrm{CV}$, either through the intensity in the search for work, or through the number of contacts with potential employers and ultimately through the presence of candidates during the interview. In fact, there is a correlation and significant interaction among these psychological attributes and behaviors, which constitute each one individually, a part of an integrated psychological mechanism, which affect job search process, interview results and eventually employability outcomes.

Therefore, except of we begin exploring the complexities of these terms it is essential to unpack the overlapping or differences between the concepts of self-efficacy, self-confidence, and self-esteem. These three terms pertain to self-perceptions, display varying levels of definitional agreement or disagreement, show theoretical and applied usage in the psychological field as closely related psychological phenomena, based on large degree in past experiences and finally influence performance and outcomes of job search. To proceed, trying to keep confusion to a minimum, these terms will be presented as much it could be, among the limits of an article, and considered to be essentially the same concept, because eventually all of them deals with the employment outcomes. In general, although most people think about self-esteem and self-confidence as two terms concerning the same thing and probably rarely 
think about the term "self-efficacy," these three terms hold slightly different meanings for the psychologists who study them (Druckman \& Bjork, 1994; Oney, \& Oksuzoglu-Guven, 2015).

\section{Self-efficacy}

Albert Bandura, (1977) defines self-efficacy as an individual's beliefs about their capacity to influence the events in their own lives. Self -efficacy refers to an individual's self assessment belief about his or her capacity in order to organize and execute behaviors necessary to produce specific desired performance attainments (Bandura, 1986; Bandura, 1997). Job search self-efficacy it is reported to be another individual difference variable as important predictor of job search behavior and employment status. Self-efficacy is i.e one's confidence in performing tasks that are important in the job search process (Bandura, 1997). The stronger people believe in their own capabilities, the greater and more persistent their efforts will be and the more likely they are to perform successfully (Bandura, 2001). This differs from self-esteem in a way that the definition of self-esteem often rests on ideas about an individual's worth or worthiness, while self-efficacy is based in beliefs about an individual capability to handle effectively future situations. In this sense, self-esteem is more of a present-focused belief in which self-worth has a pivotal role, while self-efficacy is more of a forward-looking belief, in which effectiveness and target achievement expectations have the critical role respectively.

Eden and Aviram, (1993) reported that the initial level of general self-efficacy among unemployed job-seekers related positively to job search behavior and reemployment. Self-efficacy operates on an affective level to the extent that it correlates with one's self-esteem, depressive thinking, and anxiety (Bandura, 1989, 1993). As a point of integration, self-efficacy promotes positive change in cognitive processing (information processing) and emotional state (desire to succeed in academics), which in turn, impact behavior (Bandura, 1993). According to Schreuder \& Coetzee, (2011) self-efficacy refers to people's perceptions of the level of difficulty of career-related or performance-related tasks that they believe they are going to attempt and their perceptions of how well they will be able to carry out the required actions. In addition, it refers to the extent to which their perceptions will persist despite obstacles. Solberg, Good, and Nord (1994) defined career search self-efficacy as an individuals' efficacy expectations regarding their ability to perform important activities associated with career search and selection. High level of career search self-efficacy means the degree to which an individual performs a variety of career exploration and decision-making activities, such as exploring personal values and interests, effectively networking, and successfully seeking and interviewing for positions of interest (Solberg, et al., 1995). As Solberg et al.,(1994) stated a critical area of career development is the development of skills and competencies essential to the career search and decision-making process. Career search self-efficacy encompasses four broad dimensions: job search, interviewing, networking, and personal exploration efficacy. Success in each of these four dimensions requires a mastery of the task-approach skills associated with career readiness. This set of skills may not successfully exist without strong self-efficacy.

Career self-efficacy is a sense of self-assurance in one's ability to perform actions related to 
career choices (Anderson and Betz, 2001). As a self-efficacy, specifically in job search it is considered the strong conviction, the view of the candidate, that he is capable of having that behavior and activity required in order to achieve the intended result in finding a job (Kanfer \& Hulin, 1985; Nesdale \& Pinter, 2000). The concept of self efficacy has three dimensions: level, strength-intensity and generality (Bandura, 1986). According to Betz and Voyten, (1997) high career self-efficacy typically reflects individual self-confidence in the proficient completion of career-related tasks that promote the anticipation of positive outcomes, which, in turn, will positively influence career exploration.

\section{Self Esteem}

Morris Rosenberg (1965) in his 1965 book, Society and the Adolescent Self-Image, discussed the issue of self-esteem and introduced his widely used accepted Self-Esteem Scale. His definition of self-esteem rested on the assumption that it was a relatively stable belief about one's overall self-worth. This is a broad definition of self-esteem, defining it as a trait that is influenced by many different factors and is relatively difficult to change. In contrast, Branden (1969) believes self-esteem is made up of two distinct components: self-efficacy, or the confidence we have in our ability to cope with life's challenges, and self-respect, or the belief that we are deserving of happiness, love, and success. The definitions are similar, but it is worth noting that Rosenberg's definition relies on beliefs about self-worth, a belief which can have wildly different meanings to different people, while Branden is more specific about which beliefs are involved in self-esteem. Self-esteem at high and low levels can be damaging so it is important to strike a balance in the middle. A realistic but positive view of the self is often ideal. Ellis and Taylor, (1983) concluded that global self-esteem related to social job search behaviors, such as the use of job sources and interview evaluations, as well as search outcomes. Schmit, Amel, and Ryan (1993) reported that self-esteem positively related to assertive job seeking behavior. Thus, self-esteem appears to be an important individual difference variable in job search theory and research.

Self-esteem (as a career meta-competency) is the central element of any person's daily experiences and is, therefore, an essential psychological construct. It refers to the way people feel about themselves. It reflects and affects their dealings with the environment and the people with whom they come into contact (Kernis, 2003).

Potgieter, (2012), confirmed that career meta-competencies such as self-esteem, do influence employability attribute significantly. Hence, career development support practices and career counselling interventions could be exploited from anyone who wants to reinforce his employability. There is a significant positive relationship observed between self-esteem and employability attributes suggesting that people with higher self-esteem will have higher employability attributes. Rosenberg (1965) described self-esteem as the positive or negative attitudes that people have about themselves. High self-esteem means that people feel that they are good enough whereas a low self-esteem means that they feel that they are not. Battle, (2002) describes self-esteem as the perception that people have of their self-worth. It develops gradually and becomes more differentiated with adulthood and because of interaction with others. 


\subsection{The Significance of Self-Confidence as a Skill}

Even though is a very often used term there is still some confusion about what exactly self-confidence is. According to Bénabou \& Tirole, (2002), Self-confidence refers to as simply believing in oneself. Another study refers to self-confidence as an individual's expectations of performance and self-evaluations of abilities and prior performance (Lenney, 1977). A general definition held that confidence reflects a degree of certainty about a perception, event, or outcome (e.g., Merkle \& Zandt, 2006). Self-confidence differs from self-efficacy in that self-efficacy is a specific perception about one's ability to conduct a particular behavior (Bandura, 1997). According to him the term confidence lacks a target of certainty, whereas self-efficacy targets perceived competence in a given behavior. In other words, self-efficacy represents both "affirmation of capability and strength of that belief" while confidence reflects only strength of certainty about a performance or perception (Bandura, 1997, p.382). Self-confidence is mentioned as one of the most important qualities of candidates among these of problem solving and teamwork. These properties are developed and better achieved through closer cooperation between the labour market and studies (Wickramasinghe and Perera, 2010). Self-confidence is also mentioned as one of the twenty most important among other skills currently sought by employers (Lloyd Davies 2000). According to the Bretz et al.,(1993) survey, based respectively on the research of (McGovern \& Tinsley, 1978) self-confidence, is the twelfth in order of importance, as capacity-skill taken into account, inter alia, in the process assessment and classification of candidates as to their compatibility, fit with the organization. Also, research has shown that, a key element to a successful interview is self-confidence during this, which is defined as the candidates' personal assessments of the interview skills. For this reason, the technique of role playing in interview simulation process, should primarily aim to consolidate candidates' view of their self-confidence (Tay et al., 2006). Moreover, perceived by candidates high, versus low self-esteem, personal efficiency during an interview seems to affect their performance in it (Tay, Ang, \& Van Dyne, 2006; Tross \& Maurer, 2008).

So far, it is clear that Self-confidence connects abilities with anticipated goals and successes. Thus, in a more simple interpretation self-confidence, could considered similar to self-efficacy because both tends to focus on the person future performance and targets achievement. Many psychologists tend to refer to self-efficacy when considering an individual's beliefs about their abilities concerning a specific task or set of tasks, while self-confidence is more often referred to as a broader and more stable trait concerning an individual's perceptions of overall capability.

\subsection{The Impact of Self-Confidence, Self Efficacy in Job Search, Interview Outcomes and Employability}

The confidence of the candidate during the job search plays an important role in the successful outcome of this process. The candidate's confidence is positively associated with the number of job proposals the candidate receives during job search, but also offers from the employers, the candidate he wants and prefers himself. It is also stated that self-efficacy beliefs are more effective at turning interviews into job proposals; job offers (Moynihan et al., 2003). Other research in which self efficacy on job search has been investigated, has shown that people with 
particular self-confidence are more effective in looking for work and increase the likelihood of finding job, in relation to people who are characterised by a lack of self-confidence. In fact, it is stated that self-confidence in job search is something that can be improved through appropriate workshop and that this improvement has a significant effect on employability, particularly in people who do not have a high confidence (Don Eden \& Arie Aviram, 1993). Actual, there is evidence of a strong correlation between participation in a career development program and career search self-efficacy, specifically a positive correlation between participation in the career program and high career search self-efficacy scores Specifically, there were significant positive correlations between all four career search efficacy subscales: (1) job search, (2) interviewing, (3) networking, and (4) personal exploration (Heather Maietta, 2013, p.16). According to Bandura (1997), Van der Velde and Van den Berg (2003), self-perceived employability depends on a person's self efficacy. And self-esteem - self-confidence is enhanced through a positive experience in previous situations (Hmieleski \& Corbett, 2008). In conclusion it could be improved, built by a corresponding positive experience through an educational process Simulation. Self-esteem -self-confidence in the interview has successfully increased through relevant training (Tross \& Maurer, 2008).

Job search self-efficacy also has been found that significantly influenced job search behaviors and planning behaviors (Jacquet Naïs Leroy, 2011, p.475). Overall, self confidence is positively related to successful job search (McQuaid et al., 2004). Self efficacy is noted to have a particular impact, correlation in the candidate's job search period and more specifically on his search behavior (Moynihan et al., 2003). Job search behavior can be seen as a target-driven behavior (Saks, 2005; Van Hoye \& Saks, 2008) designed for the candidate to head him or her, from the current situation which is unemployment to the desired situation, employment. Regarding job search context, the relationship between a particular job search behavior and job offers might be more positive for job seekers with higher self-efficacy beliefs for that specific behavior, because these beliefs relate to the quality and confidence with which the behavior is performed increasing the likelihood that the behavior will be successful (Van Hooft, Wanberg, \& Van Hoye, 2013). But, what factors increase a candidate's self efficacy esteem? It is stated that the main factor at least between the degree score, the overall work experience, employment during the summer, and the taking of leadership roles is that of takeover the candidate of leading roles in various forms of activity (Moynihan et al., 2003). And candidates who actively participate in such social activities are according to another survey that distinguishes themselves for the extroversion of their character (Burger \& Caldwell, 2000). This particular positive feature of their personality also has a positive impact on job search because it favours them in enabling and expanding their personal network of acquaintances as well as achieving a second, follow up, interview after the original (Burger \& Caldwell, 2000). It has also been found that the candidate's self efficacy has a particularly positive impact on the intensity, passion with which the candidate seeks a job (Wanberg, et al., 1999; Eden \& Aviram, 1993; Ellis \&Taylor, 1983; Kanfer \& Hulin, 1985; Van Ryn \& Vinocur, 1992). The job search intensity refers to the frequency at which jobseekers, within a certain period of time, adopt behaviors and engage in activities aimed at finding a job (Saks, 2006). This intensity in job search in turn improves employability (Klepinger et al., 2002; Wanberg, et al., 1999; Kanfer et al., 2001; Barron \& Mellow, 1981; Feather \& O’Brien, 1987; Wanberg, 1997). In the mood for 
an intensive job search of a candidate, apart from his self-confidence, significant contribution has also his ability to effectively control his emotion and his motivation skills for work. It should be noted that this ability to control, to dominate someone his motivation, is particularly important for the intensity of the job search, especially for those who have been unemployed for more than three months after their first contact with an employer. It is emphasized, that this ability to control emotion, motivational skills, is perhaps more effective in maintaining tension in the search for work, than the self-efficacy or the candidate's financial hardship (Wanberg et al., 1999). Self-confidence also involves and affects the way the candidate presents himself during the interview. More specifically, according to Dipboye and Wiley, (1977) research, the candidate's personal style is a key factor in the decisions of the interviewers' and the interviewees are capable of such influences towards interviewers. In fact, it is stated that while the candidates who participated in a survey sample had exactly the same highly qualifications' and specifically good scores and highly qualified relative work experience as they referred to in their resumes, however, the candidates who presented themselves and their qualifications in a more 'aggressive', moderately way, were seen by the interviewees as more capable, attractive and in particular as having more important professional experience and education as well as somewhat better academic record, thus giving them the lead for a second interview or proposing them for recruitment. On the contrary, the candidates who passively presented themselves had the opposite effects (Dipboye and Wiley, 1977, p.6,11). In general, the criteria, factors which have been assessed by the interviewers for candidates' in this study, were the certainty- assertion with weightiness of $65.5 \%$, then the social sensitivity with weightiness of $19.8 \%$ and the third social facade with weightiness $8.8 \%$ respectively (Dipboye and Wiley, 1977, p.5). To clarify exactly what aggressive style means and what differs from passive style, we mention that candidates who are 'characterized' as more dynamic-aggressive are distinguished from the others who are passive, in terms of being less shy, answering not monologues but demoralising interviewer questions, speaking in a more pronounced voice, maintaining more frequent and more extensive eye contact and expressing themselves with particular confidence (Dipboye and Wiley, 1977, p. 4).

\section{Methodology}

To study the research questions about the relative impact that self confidence might have on selection interview process, a primary field research was conducted. In the empirical survey, participants were asked through a structured questionnaire to state the extent of possibility and significance they accredit to applicants' self confidence during interview selection process. In particular we examine the possible influence could have self-confidence of candidates on recruiters, employers hiring decisions during interview process.

\subsection{Formulation of Research Questions}

In order to formulate the questions for the level of significance of candidates self confidence at the stage of interview process, various research have been taken into account related to the staff selection interview process. So, the focus was on three versions of results that are the most common success indicators of an interview as evidenced by the majority of the literature review. According to them, an employment interview usually has the ultimate goal or often 
ends in the following, hire or recommendation to hire (Gilmore \& Ferris 1989, p.561, 562; Higgins \& Judge 2004), b) possibility of inviting candidates to a second interview (Burger \& Caldwell., 2000, p. 51-62; Caldwell \& Burger., 1988, p.126; Wei-Chi Tsai, et al., 2005 p.113; Stevens \& Kristof, 1995) and to consider a candidate as suitable for the job position (Kinicki \& Lockwood, 1985; Wei-Chi Tsai, et al., 2005, p.113; Stevens \& Kristof, 1995). Based on these indicators, the influence of candidates' self confidence on recruiters hiring decisions during interview process, was examined in respect to the following choices a) to hire them, b) to consider them suitable for the position and c) to give them a chance for a second interview. So, the following question among many others was placed to the questionnaire, in order to measure the impact of candidates' self confidence on the evaluators' decisions '

'When you choose a candidate for a job through employment interview process, how much importance you attach to the self-confidence that he demonstrates in order to: a) hire him, b) consider him suitable for the position and c) give him a chance for a second interview'

As self-confidence, self efficacy, particular in job search, defined the candidate's strong belief, view that he is capable of having that behavior and activity needed in order to achieve the intended result in job search (Canfer \& Hulin, 1985; Nesdale \& Pinter, 2000) and also the candidate's view of his interviewing skills (Bretz et al., 1993 p.317). Participants were able to respond to a Likert Scale scale from one 1= not important, to five where 5= exceptional important

\subsection{Research Hypothesis}

Research Hypothesis 1: There is a positive correlation between candidates Self confidence and recruiters decision for hiring them

Research Hypothesis 2: There is a positive correlation between candidates Self confidence and recruiter's decision for consider them suitable for the job position

Research Hypothesis 3: There is a positive correlation between candidates Self confidence and recruiters decision for inviting them in a second interview

Research Hypothesis 4: There is a positive correlation between candidates Self confidence and recruiters decisions in hire-ability consolidated index

\subsection{Questionnaire Design}

The questionnaire was divided in two parts. First part was regard to resume and characteristics on it that are considered important factors that recruiters evaluate in stage of screening applicants throw their resumes. Second part referred to interview process and attributes, qualifications of candidates that considered significant by recruiters during selection process. Questionnaire was constituted of fifty five questions of which twenty three of them referred to resume, thirty referred to interview process and two was referred to selection methods. The questions concerned the investigation of the impact and degree of importance of a number of characteristics and qualifications of candidates that employers', interviewers take into account at the stage of examination of CVS and during interview process. Indicatively, among others, they were investigated as such characteristics of the 
candidates' demographics attributes, formal qualifications, studies, relative or irrelative working experience, previous status of employment or unemployment spells, personality, employability skills, personality types, verbal communication and body language, physical attractiveness, person to the job fit, person to organization fit, extracurricular activities, Self confidence, and other important criteria.

\subsection{Research Sample}

A total of two hundred sixty (260) questionnaires were gathered fully completed. The questionnaire was distributed to various businesses all over Greece, printed one by one, with face to face communication and contact with participants. An initial telephone communication or an email was conducted in order to inform them about the survey and to ask for the permission for their participation. This process was considered as most appropriate first because it provided the opportunity for interaction with the participants and gave the opportunity to provide additional information and clarifications on the questionnaire and the research, and secondly had the advantage of gathering a large number of questionnaire replies in a relatively short time that ensures the homogeneity, validity and relevance of the sample. Sample has covered all businesses sizes such as small, medium, large and very large companies. The questionnaire records and portrays personal assessments, evaluations of participants, as it is customary to apply as a practice in relevant scientific research (Saunders, \& Zuzel, 2010). The sample of two hundred and sixty people (N=260) included participants as an employer, human resources manager, professional recruitment consultants and executives, directors who are responsible for recruiting workers from different work fields, sectors such as commerce, industry, manufactures, services, telecoms, constructions and different geographic areas.

\section{Gender of participants}

The majority of participants in the sample were male $(67.7 \%)$, followed by the percentage of female $(32.3 \%)$

\section{Participant's work sector}

The largest share $(81.2 \%)$ of the respondents were from private sector companies, $(12.7 \%)$ work in HR consulting companies, and the remaining (6.2\%) work in Public sector for common wealth companies

\section{Size of businesses}

The majority of businesses were very small firms (42.3\%) and small (18.5\%) which are the main backbone of entrepreneurship in Greece. Medium-sized enterprises were the $8.8 \%$ of the sample, large sized enterprises constitute the $10.4 \%$, very large enterprises were the $8.1 \%$ and megafirms were the rest $11.9 \%$ of the total sample

\section{Work position}

The largest share $(30 \%)$ of the sample participants were employers, $(26.5 \%)$ were Head of Department, (21.2\%) were Professionals Recruiters, (13.1\%) were Personnel Managers' and 


\section{Macrothink}

the remaining (9.2\%) were Chief Executive Officers-CEO

\section{Statistic Analysis}

In order to present the answers given during the interviews, frequency allocation tables were constructed for each question in the questionnaire. The Spearman correlation coefficient was calculated to investigate the correlation between respondent opinions / attitudes. The checks were carried out at a confidence level of 0,05. Analyzes were conducted using IBM SPSS Statistics (IBM SPSS Statistics for Windows, version 19 (IBM Corp., Armonk, N.Y., USA)

\subsection{Reliability Analysis}

For the stage of interview selection process regarding candidates' self confidence impact, on recruiting decisions the three choices of the interviewers a) to hire them, b) to consider them suitable for the position and c) to give them a chance for a second interview, have been unified in one index, which the term 'hireability, sellectability'. This term, has been also used in other studies (Cuddy, et al, 2015; Knouse, 1994).

The values of this new index were calculated for each participant in the sample as the average of the above three grades of agreement. The new indicator (Hireability, Sellectability) were tested for their credibility by calculating the Cronbach's alpha factor for the stage of interview process. The results of the credibility analysis showed that indicators are reliable in all cases with Cronbach's alpha getting values of 0.849 greater than 0.7 which is defined as acceptable according to literature. Reliability analysis of candidates' self-confidence impact on hireability index on stage of interview process (Tables 1,2)

Table 1. Item-Total Statistics

\begin{tabular}{|l|r|r|r|r|}
\hline $\begin{array}{l}\text { Self } \\
\text { Confidence }\end{array}$ & $\begin{array}{c}\text { Scale Mean if } \\
\text { Item Deleted }\end{array}$ & $\begin{array}{c}\text { Scale } \\
\text { Variance if } \\
\text { Item Deleted }\end{array}$ & $\begin{array}{c}\text { Corrected } \\
\text { Item-Total } \\
\text { Correlation }\end{array}$ & $\begin{array}{c}\text { Cronbach's } \\
\text { Alpha if Item } \\
\text { Deleted }\end{array}$ \\
\hline Hire & 7,5038 & 2,019 &, 677 &, 826 \\
\hline Suitable & 7,6500 & 1,835 &, 783 &, 725 \\
\hline $\begin{array}{l}\text { Second } \\
\text { Interview }\end{array}$ & 7,6308 & 1,894 &, 695 &, 812 \\
\hline
\end{tabular}

Table 2. Reliability Statistics

\begin{tabular}{|r|r|}
\hline Cronbach's Alpha & N of Items \\
\hline, 849 & 3 \\
\hline
\end{tabular}

\section{Results and Findings}

\subsection{Descriptive Analysis Results}

The influence, importance of candidate's Self-confidence on the selection decisions of employers, recruiters in interview process

In Table (7), we see the average of the sample participants' responses on the impact of 


\section{Macrothink}

International Journal of Human Resource Studies

ISSN 2162-3058 2020, Vol. 10, No. 2

candidates' self-confidence on employers' decisions to consider a candidate as suitable for employment- recruitment at the stage of evaluation them during interview process

On the basis of the descriptive statistical analysis we note that the candidate's confidence is in average, $M=3.7974$, well above the average weighting of the Likert scale, which means that as a criterion is perceived by the employers quite, to very important in their decisions in order to consider candidates as suitable for employment- recruitment for a job. Thus candidates, who have this qualification-attribute, are most likely to be considered eligible, employable for a job according to the eligibility, hireability index which previously defined.

Table 7. Mean of Self confidence significance

Descriptive Statistics

\begin{tabular}{|l|l|r|r|r|r|}
\hline & $\mathrm{N}$ & Minimum & Maximum & Mean & $\begin{array}{c}\text { Std. } \\
\text { Deviation }\end{array}$ \\
\hline Self Confidence & 260 & 2,33 & 5,00 & 3,7974 &, 66730 \\
\hline Valid N (listwise) & 260 & & & & \\
\hline
\end{tabular}

\subsection{Linear Regression Analysis results}

For the interview stage, we defined as a depended variable the importance of the interview. The three options of the interviewers during interview were (a) the possibility to hire the candidate (b) to consider him suitable for the position, (c) to invite him for a second interview, on the basis of the importance that candidate's self confidence has on that specific decisions of the recruiters.

The importance of self-confidence in the decision of the interviewers to hire the candidate

The overall interpretation index of the criterion is $\mathrm{R}^{2}=0.171$

Model Summary

\begin{tabular}{|l|c|r|r|r|}
\hline Model & R & R Square & $\begin{array}{c}\text { Adjusted R } \\
\text { Square }\end{array}$ & $\begin{array}{c}\text { Std. Error of } \\
\text { the Estimate }\end{array}$ \\
\hline 1 &, $414^{\mathrm{a}}$ &, 171 &, 168 &, 75431 \\
\hline
\end{tabular}

Beta standardized coefficient is $(\beta)=0.414$, ( $\mathrm{p}$-value), $\mathrm{p}=0.000<0.05$. It is therefore proven, that the candidate's self confidence, has a statistically significant influence on the decision of the interviewers to hire the candidate. 


\section{Coefficients $^{\mathrm{a}}$}

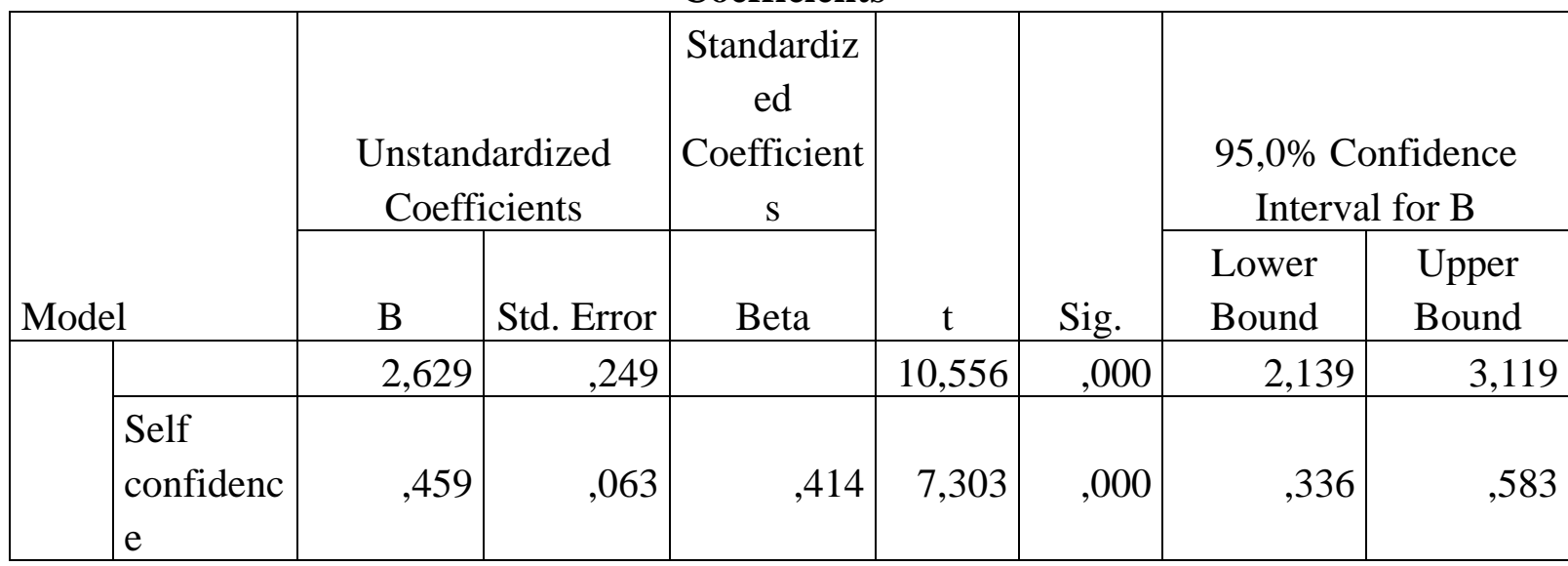

$(*: p<0.05)$

The importance of self-confidence in the decision of the interviewers to invite the candidate for a second interview

The overall interpretation of the criterion is $\mathrm{R}^{2}=0.099$

Model Summary

\begin{tabular}{|l|l|r|r|r|}
\hline Model & $\mathrm{R}$ & R Square & $\begin{array}{c}\text { Adjusted R } \\
\text { Square }\end{array}$ & $\begin{array}{c}\text { Std. Error of } \\
\text { the Estimate }\end{array}$ \\
\hline &, $315^{\mathrm{a}}$ &, 099 &, 096 &, 81766 \\
\hline
\end{tabular}

Beta standardized coefficient is $(\beta)=0.315$, ( $p$-value), $p=0.000<0.05$. It is therefore proven, that the candidates' self-confidence has a statistically significant influence on the decision of the interviewers, to give the candidate the opportunity, invite him/her for a second interview

\section{Coefficients $^{\mathrm{a}}$}

\begin{tabular}{|c|c|c|c|c|c|c|c|}
\hline \multirow[b]{2}{*}{ Model } & \multicolumn{2}{|c|}{$\begin{array}{c}\text { Unstandardized } \\
\text { Coefficients }\end{array}$} & \multirow{2}{*}{$\begin{array}{c}\begin{array}{c}\text { Standardize } \\
\mathrm{d}\end{array} \\
\text { Coefficients } \\
\text { Beta } \\
\end{array}$} & \multirow[b]{2}{*}{$\mathrm{t}$} & \multirow[b]{2}{*}{ Sig. } & \multicolumn{2}{|c|}{$\begin{array}{l}95,0 \% \text { Confidence } \\
\text { Interval for B }\end{array}$} \\
\hline & $\mathrm{B}$ & $\begin{array}{l}\text { Std. } \\
\text { Error }\end{array}$ & & & & $\begin{array}{l}\text { Lower } \\
\text { Bound }\end{array}$ & $\begin{array}{l}\text { Upper } \\
\text { Bound } \\
\end{array}$ \\
\hline $\mid \begin{array}{l}\text { Self } \\
\text { confidenc }\end{array}$ & 3,056 & ,249 & & 12,274 & ,000 & 2,566 & 3,546 \\
\hline &, 345 &, 065 &, 315 & 5,325 & ,000 & ,217 &, 473 \\
\hline
\end{tabular}

$(*: \mathrm{p}<0.05)$

The importance of self-confidence in the decision of the interviewers to consider the candidate suitable for the position

The overall interpretation of the criterion is $\mathrm{R}^{2}=0.130$ 
Model Summary

\begin{tabular}{|l|c|r|r|r|}
\hline Model & R & R Square & $\begin{array}{c}\text { Adjusted R } \\
\text { Square }\end{array}$ & $\begin{array}{r}\text { Std. Error of } \\
\text { the Estimate }\end{array}$ \\
\hline 1 &, $360^{\mathrm{a}}$ &, 130 &, 126 &, 75751 \\
\hline
\end{tabular}

Beta standardized coefficient is $(\beta)=0.360$, (p-value), $\mathrm{p}=0.000<0.05$. It is therefore proven, that the self-confidence of the candidates, has a statistically significant influence on the decision of the interviewees to consider the candidate suitable for the position

Coefficients $^{\mathbf{a}}$

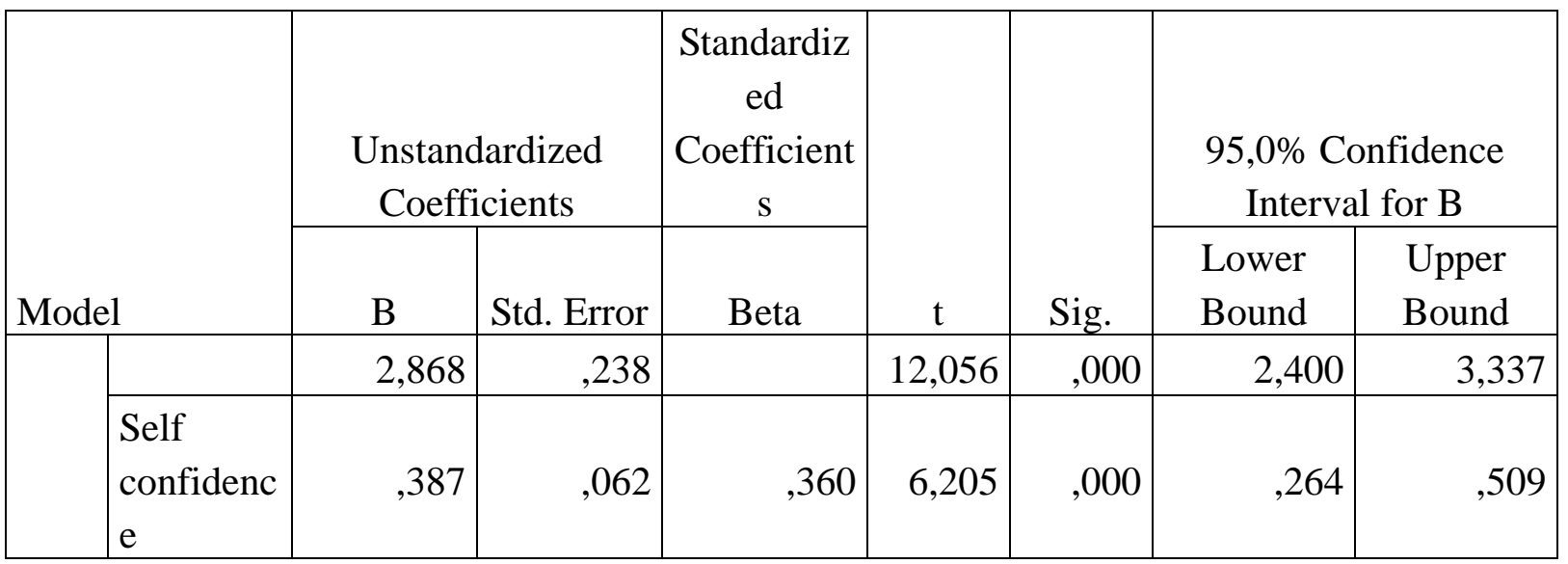

$(*: p<0.05)$

In a next step of regression analysis the three decisions options of the recruiters, consolidated into a single dependent variable which is called Hireability index. In essence, the importance of the self confidence in the process of selecting staff with interview process is expressed through this indicator which takes into consideration the three interviewer's decisions-options as one.

The importance of the influence of the candidate's Self-confidence in relation to Hireability, unified index

The degree of overall interpretation of the criterion is $\mathrm{R}^{2}=0.172$

Model Summary

\begin{tabular}{|l|c|r|r|r|}
\hline Model & R & R Square & $\begin{array}{c}\text { Adjusted R } \\
\text { Square }\end{array}$ & $\begin{array}{c}\text { Std. Error of } \\
\text { the Estimate }\end{array}$ \\
\hline 1 &, $414^{\mathrm{a}}$ &, 172 &, 168 &, 68262 \\
\hline
\end{tabular}

According to simple regression analysis results we see that beta standardized coefficient is $(\beta)$ $=0.414,(\mathrm{p}$-value $), \mathrm{p}=0.000, \mathrm{p}<0.05$.

Thus, the applicant's self-confidence has a statistically significant influence on the decision of employers, interviewers according to the Hireability, eligibility unified index, which has been set out in our methodology 
$(*: p<0.05)$

\begin{tabular}{|r|l|r|r|r|}
\hline \multicolumn{2}{|l|}{} & \multicolumn{1}{|c|}{ Beta } & & \\
\hline \multirow{2}{*}{$\begin{array}{l}\text { Self } \\
\text { confidence }\end{array}$} & & 10,597 &, 000 \\
\cline { 2 - 5 } & & $\mathbf{4 1 4}$ & $\mathbf{7 , 3 1 1}$ & $\mathbf{, 0 0 0 *}$ \\
\hline
\end{tabular}

\section{Conclusions and Discussion}

All, four hypotheses have been supported. The results confirms that candidates' self confidence has a significant affect in all recruiters decisions, specifically to their decisions to hire them, to consider them suitable for a position and to invite them in a second interview giving them a second chance. The results also demonstrate that the self-confidence of candidates as a characteristic is statistically significant and affects the decisions of interviewers, employers according to the overall hireability, eligibility index we have created, which proves the importance of this factor. The results of this research are consistent in many ways, with the results of other surveys on the importance of self-confidence. Either because the importance of self confidence, is explained by the fact that as a characteristic, may be linked to qualities such as initiative, guidance, motivation, administration, persuasion, orientation in achieving objectives, elements that are encountered in the field of leaders in the world of business (ILO, 2013), or because as a characteristic contributes to the dynamic presence of the candidate in the interview (Dipboye and Wiley, 1977), or because it is one of the most important skills sought by employers (Lloyd Davies, 2000; Bretz, et al.,1993;Wickramasinghe and Perera, 2010), either because self-confidence is positively associated with the number of job proposals the candidate receives during job search essays and offers also from employers preferred by the candidate himself, or because self-efficacy beliefs are more effective at turning interviews in job offers (Moynihan, et al.,2003), or because affect positive the job search behavior (Van Hooft, Wanberg, \& Van Hoye, 2013), either because contribute to be given them a chance for a second interview (Burger \& Caldwell, 2000), either because self confidence is considered a key element for a successful interview (Tay et al., 2006).

\section{Research Contribution and Implications}

There is argument that interviewee performance and state of mind variables e.g., interview motivation, should continue to receive attention. The triple combination and high correlation of 'interview state' constructs, of interviewing experience, interview motivation, interview self-efficacy and interview ratings, suggests that they play a stronger role than generally recognized (Huffcutt, 2011, p.74).

The importance and contribution of this study is crucial in order to investigate what factors influence employers', recruiter's decisions during interview. By gaining what is essential for them, this study could help both applicants for transition to work and learning institutions or government authorities for employment services. Since it has been proven that self confidence has significant influence in employment interview outcomes and specific recruiter's decisions respectively, it is implied that employee candidates should take over actions to enhance their self confidence level. 


\section{Macrothink

Due to the fact that self confidence can be strengthened (Heather Maietta, 2013, p.16; Tross \& Maurer, 2008) by specific actions such as training, job search consulting programs, participation in relative career and employment interview simulations courses, applicants should take advantage of attending such curriculums which can support them on acquire self confidence, enhance their employability skills and increase applicants interview performance (Beddie et al., 2005; Maurer, et al.,2001; Silvester et al.,2002). Furthermore has been proved that candidates need support to their employment skills and they agree that such employability training programs are necessary and useful for their employability (Dimopoulos, 2019).

On the other hand, policy makers, educational institutes, government employment agencies should take over, organize and implement relative courses to provide the appropriate support to unemployed people, to enhance their self confidence in order to improve their employability accordingly.

\section{References}

Anderson S. L., \& Betz N. E. (2001). Sources of social self-efficacy expectations: Their measurement and relation to career development. Journal of Vocational Behavior, 58, 98-117. https://doi.org/10.1006/jvbe.2000.1753

Bandura, A. (1977). Self-efficacy: Toward a unifying theory of behavioral change. Psychological Review, 84, 191-215. https://doi.org/10.1037/0033-295X.84.2.191

Bandura, A. (1986). Social foundations of thought and action: A social cognitive theory. Englewood Cliffs, NJ: Prentice - Hall.

Bandura, A. (1989). Human agency in social cognitive theory. American Psychologist, 44, 1175-1184. https://doi.org/10.1037/0003-066X.44.9.1175

Bandura, A. (1993). Perceived self-efficacy in cognitive development and functioning. Educational Psychologist, 28, 117-148. https://doi.org/10.1207/s15326985ep2802_3

Bandura, A. (1997). Self-Efficacy: The exercise of control. New York: W.H. Freeman and Company.

Bandura, A. (2001). Social cognitive theory: An agentic perspective. Annual Review of Psychology, 52, 1-26. https://doi.org/10.1146/an- nurev.psych.52.1.1

Barron, J. M., \& Mellow, W. (1981). Changes in labor force status among the unemployed. Journal of Human Resources, 16, 427-441. https://doi.org/10.2307/145630

Battle, J. (2002). Culture-Free Inventories Examiner's Manual. (3rd ed.). Austn, TX: Pro-Ed.

Beddie, F., Lorey, B., \& Pamphilon, B. (2005).Enhancing career development: the role of community based career guidance for disengaged adults. NCVER, Australian Government.

Bénabou, R., \& Tirole, J. (2002). Self-confidence and personal motivation. Quarterly Journal of Economics, 117, 871-915. https://doi.org/10.1162/003355302760193913 
Betz, N. E., \& Voyten, K. K. (1997). Efficacy and outcome expectations influence career exploration and decidedness. The Career Development Quarterly, 46(2), 179-189. https://doi.org/10.1002/j.2161-0045.1997.tb01004.x

Branden, N. (1969). The psychology of self-esteem. Los Angeles, CA: Nash Publishing.

Brewer, L. (2013). Enhancing youth employability: What? Why? And How? Guide to core work skills. ILO.

Burger, J. M., \& Caldwell, D. F. (2000). Personality, social activities, job-search behavior and interview success: Distinguishing between PANAS trait positive affect and NEO extraversion. Motivation and Emotion, 24(1), 51-62. https://doi.org/10.1023/A:1005539609679

Caldwell, D. F., \& Burger, J. M. (1998). Personality characteristics of job applicants and success in screening interviews. Personnel Psychology, 51(1), 119-136. https://doi.org/10.1111/j.1744-6570.1998.tb00718.x

Davies, L. (2000). Why kick the "L" out of "LEarning"? The development of students' employability skills through part-time working. Education+ Training. https://doi.org/10.1108/00400910010379961

Dimopoulos, A. (2019). The Significance of Employability Training Courses According to Graduate Views: Empirical Research for Greece. International Journal of Human Resource Studies, 9(2). https://doi.org/10.5296/ijhrs.v9i2.14864

Dipboye, R. L., \& Wiley, J. W. (1977). Reactions of College Recruiters to Interviewee Sex and Self- Presentation Style. Journal of Vocational Behavior, 10, 1-12. https://doi.org/10.1016/0001-8791(77)90036-7

Druckman, D., \& Bjork, R. A. (Eds.). (1994). Learning, remembering, believing: Enhancing human performance. National Academy Press: Washington, D.C., US.

Eden, D., \& Aviram, A. (1993). Self-efficacy training to speed reemployment: Helping people to help themselves. Journal of applied Psychology, 78(3), 352. https://doi.org/10.1037/0021-9010.78.3.352

Ellis, R. A., \& Taylor, M. S. (1983). Role of self-esteem within the job-search process. Journal of Applied Psychology, 68, 632-640. https://doi.org/10.1037/0021-9010.68.4.632

Feather, N. T., \& O'Brien, G. W. (1987). Looking for employment: an expectancy-valence analysis of job seeking behavior among school-leavers. Journal of Occupational Psychology, $59,121-144$.

Fort, I., Jacquet, F., \& Leroy, N. (2011). Self-efficacy, goals, and job search behaviors. Career Development International. http://dx.doi.org/10.1108/13620431111168886

Gilmore, D. C., \& Ferris, G. R. (1989). The effects of applicant impression management tactics on interviewer judgments. Journal of Management, 15(4), 557-564. https://doi.org/10.1177/014920638901500405 
Heather, M. (2013).THE FOUR YEAR EXPERIENCE: CAREER SEARCH SELF-EFFICACY OF NEW GRADUATES. Online Journal for Workforce Education and Development, 6(1).

Higgins, C. A., \& Judge, T. A. (2004). The effect of applicant influence tactics on recruiter perceptions of fit and hiring recommendations: a field study. Journal of Applied Psychology, 89 (4), 622. https://doi.org/10.1037/0021-9010.89.4.622

Hmieleski, K. M., \& Corbett, A. C. (2008). The contrasting interaction effects of improvisational behavior with entrepreneurial self-efficacy on new venture performance and entrepreneur work satisfaction. Journal of business venturing, 23(4), 482-496. https://doi.org/10.1016/j.jbusvent.2007.04.002

Holland, E., Wolf, E. B., Looser, C., \& Cuddy, A. (2017). Visual attention to powerful postures: People avert their gaze from nonverbal dominance displays. Journal of Experimental Social Psychology, 68, 60-67. https://doi.org/10.1016/j.jesp.2016.05.001

Huffcutt, A. I. (2011). An empirical review of the employment interview construct literature. International Journal of Selection and Assessment, 19(1), 62-81. https://doi.org/10.1111/j.1468-2389.2010.00535.x

Kanfer, R., \& Hulin, C. L. (1985). Individual differences in successful job searches following $\begin{array}{llll}\text { lay-off. Personnel } & \text { Psychology, } & \text { 835-847), }\end{array}$ https://doi.org/10.1111/j.1744-6570.1985.tb00569.x

Kanfer, R., Wanberg, C. R., \& Kantrowitz, T. M. (2001). Job search and employment: A personality-motivational analysis and meta-analytic review. Journal of Applied Psychology, 86(5), 837-855. https://doi.org/10.1037/0021-9010.86.5.837

Kernis, M. (2003). Toward a conceptualizatons of optmal self-esteem. Psychological Inquiry, 14(1), 1-26. htp://dx.doi.org/10.1207/S15327965PLI1401_01

Kinicki, A. J., \& Lockwood, C. A. (1985). The interview process: An examination of factors recruiters use in evaluating job applicants. Journal of Vocational Behavior, 26(2), 117-125. https://doi.org/10.1016/0001-8791(85)90012-0

Klepinger, D. H., Johnson, T. R., \& Joesch, J. M. (2002). Effects of unemployment insurance work-search requirements: The Maryland experiment. ILR Review, 56(1), 3-22. https://doi.org/10.1177/001979390205600101

Knouse, S. B. (1994). Impressions of the resume: The effects of applicant education, experience, and impression management. Journal of Business and Psychology, 9(1), 33-45. https://doi.org/10.1037/0021-9010.86.5.837

Lenney, E. (1977). Women's self-confidence in achievement settings. Psychological Bulletin, 84, 1-13. https://doi.org/10.1037/0033-2909.84.1.1

Maurer, T. J., Solamon, J. M., Andrews, K. D., \& Troxtel, D. D. (2001). Interviewee coaching, preparation strategies and response strategies in relation to performance in situational 
employment interviews: An extension of Maurer, Solamon, and Troxtel (1998). Journal of Applied Psychology, 86, 709-717. https://doi.org/10.1037//0021-9010.86.4.709

McGovern, T. V., \& Tinsley, H. E. A. (1978). Interviewer evaluations of interviewee nonverbal behavior. Journal of Vocational Behavior, 13, 163-171. https://doi.org/10.1016/0001-8791(78)90041-6

McQuaid, R. W., Greig, M., \& Adams, J. (2004). Are new deal employment initiatives on target?. International Journal of Manpower. https://doi.org/10.1108/01437720410554124

Merkle, E. C., \& Van Zandt, T. (2006). An application of the Poisson race model to confidence calibration. Journal of Experimental Psychology: General, 135(3), 391. https://doi.org/10.1037/0096-3445.135.3.391

Moynihan, L. M., Roehling, M. V., LePine, M., \& Boswell, W. R. (2003). A longitudinal study of the relationships among job search self-efficacy, job interviews, and employment outcomes. Journal of Business and Psychology, 18(2), 207-233. https://doi.org/10.1023/A:1027349115277

Nesdale, D., \& Pinter, K. (2000). Self efficacy and the job seeking activities in unemployed ethnic youth. The Journal of Social Psychology, 140(5), 608-614. https://doi.org/10.1080/00224540009600500

Oney, E., \& Oksuzoglu-Guven, G. (2015). Confidence: A critical review of the literature and an alternative perspective for general and specific self-confidence. Psychological Reports, 116, 149-163. https://doi.org/10.2466/07.PR0.116k14w0

Potgieter, I. (2012). The relationship between the self-esteem and employability attributes of postgraduate business management students. SA Journal of Human Resource Management, 10(2), 1-15. https://doi.org/10.4102/sajhrm.v10i2.419

Rosenberg, M. (1965). Society and the adolescent self-image. Princeton: Princeton Univer. Press. https://doi.org/10.1515/9781400876136

Rynes, S. L., \& Gerhart, B. (1993). Recruiter perceptions of applicant fit: Implications for individual career preparation and job search behavior. Journal of Vocational behavior, 43(3), 310-327. https://doi.org/10.1006/jvbe.1993.1050

Saks, A. M. (2005). Job search success: A review and integration of the predictors, behaviors and outcomes. In S. D. Brown, \& R. W. Lent (Eds.), Career development and counseling: Putting theory and research to work (pp. 155-179). Hoboken, New Jersey: John Wiley \& Sons.

Saks, A. M. (2006). Multiple predictors and criteria of job search success. Journal of Vocational Behavior, 68(3), 400-415. https://doi.org/10.1016/j.jvb.2005.10.001

Saunders, V., \& Zuzel, K. (2010). Evaluating employability skills: Employer and student perceptions. Bioscience education, 15(1), 1-15. https://doi.org/10.3108/beej.15.2

Schmit, M. J., Amel, E. L., \& Ryan, A. M. (1993). Self-reported assertive job-seeking 
behaviors of minimally educated job hunters. Personnel Psychology, 46(1), 105-124. https://doi.org/10.1111/j.1744-6570.1993.tb00869.x

Schreuder, A., \& Coetzee, M. (2011). Careers: an organisatonal perspectve. Cape Town: Juta.

Solberg, V. S., Good, G. E., \& Nord, D. (1994). Career search efficacy: Ripe for applications and intervention programming. Journal of Career Development, 21, 63-72. https://doi.org/10.1007/BF02107104

Solberg, V. S., Good, G. E., Fischer, A. R., Brown, S. D., \& Nord, D. (1995). Career decision making and career search activities: Relative effects of career search self-efficacy and human agency. Journal of Counseling Psychology, 42, 448-455. https://doi.org/10.1037/0022-0167.42.4.448

Stevens, C. K., \& Kristof, A. L. (1995). Making the right impression; A field study of applicant impression management during job interviews. Journal of Applied Psychology, 80, 587-606. https://doi.org/10.1037/0021-9010.80.5.587

Tay C., Ang S., \& Van Dyne L. (2006). Personality, Biographical Characteristics, and Job Interview Success: A Longitudinal Study of the Mediating Effects of Interviewing SelfEfficacy and the Moderating Effects of Internal Locus of Causality. Journal of Applied Psychology, 91(2), 446-454. https://doi.org/10.1037/0021-9010.91.2.446

Tross, S. A., \& Maurer, T. J. (2008). The effect of coaching interviewees on subsequent interview performance in structured experience-based interviews. Journal of Occupational and Organizational Psychology, 81, 589-605. https://doi.org/10.1348/096317907X248653

Tsai, W. C., Chen, C. C., \& Chiu, S. F. (2005). Exploring boundaries of the effects of applicant impression management tactics in job interviews. Journal of Management, 31(1), 108-125. https://doi.org/10.1177/0149206304271384

Van der Velde, M., \& Van den Berg, P. (2003). Managing functonal flexibility in a passanger transport frm. Human Resource Management Journal, 13(4), 45-55. htp://dx.doi.org/10.1111/j.1748-8583.2003.tb00104.x

Van Hooft, E. A. J., Wanberg, C. R., \& Van Hoye, G. (2013). Moving be- yond job search quantity: Towards a conceptualization and self-regulatory framework of job search quality. Organizational Psychology Review, 3, 3-40. https://doi.org/10.1177/2041386612456033

Van Hoye, G., \& Saks, A. M. (2008). Job search as goal-directed behavior: Objectives and methods. Journal of Vocational Behavior, 73, 358-367. https://doi.org/10.1016/j.jvb.2008.07.003

Van Ryn, M., \& Vinocur, A. D. (1992). How did it work? An examination of the mechanisms through which an intervention for the unemployed promoted job search behavior. American Journal of Community Psychology, 20, 577-597. https://doi.org/10.1007/BF00941773

Wanberg, C. R. (1997). Antecedents and outcomes of coping behaviors among unemployed and reemployed individuals. Journal of Applied Psychology, 82, 731-744. 
https://doi.org/10.1037/0021-9010.82.5.731

Wanberg, C. R., Kanfer, R., \& Rotundo, M. (1999). Unemployed individuals: Motives, job-search competencies, and job-search constraints as predictors of job seeking and $\begin{array}{lllll}\text { reemployment. Journal of Applied } & \text { psychology, }\end{array}$ https://doi.org/10.1037/0021-9010.84.6.897

Wickramasinghe, V., \& Perera, L. (2010). Graduates', university lecturers' and employers' perceptions towards employability skills. Education+ Training, 52(3), 226-244. https://doi.org/10.1108/00400911011037355

\section{Copyright Disclaimer}

Copyright for this article is retained by the author(s), with first publication rights granted to the journal.

This is an open-access article distributed under the terms and conditions of the Creative Commons Attribution license (http://creativecommons.org/licenses/by/4.0/). 